\title{
USDA SEDIMENTATION LABORATORY RADIOCARBON DATES I
}

\author{
L. L. McDOWELL and M. E. RYAN
}

U. S. Department of Agriculture, * Agricultural Research Service, Soil and Water Conservation Research Division, Oxford, Mississippi

The radiocarbon dating laboratory at the USDA Sedimentation Laboratory was established to supplement current watershed geomorphologic investigations. The principal objective of the program is to provide information on valley aggradation rates and sequences.

Liquid scintillation counting of benzene is employed (Tamers et al., 1961; Noakes et al., 1963; McDowell and Ryan, 1964). The chemical synthesis of benzene has been modified to increase the carbon yield and to decrease the man-hours required per sample.

All samples are visually inspected for contaminants, which are removed from the sample before chemical pretreatment. Wood and charcoal are washed with hot $3 \mathrm{~N} \mathrm{NaOH}$, distilled water, hot $3 \mathrm{~N} \mathrm{HCl}$, and finally with distilled water. Samples of peat, soil, and animal residues (size permitting) are subjected to more rigorous pretreatment resulting in the separation of crude fractions of "cellulose" and "lignin" (Olson and Broecker, 1958).

The general method for the synthesis of benzene from the original sample is given by the following reactions:

1. Sample $+\mathrm{O}_{2} \longrightarrow \mathrm{CO}_{2}+\mathrm{H}_{2} \mathrm{O}$

2. $\mathrm{CO}_{2}+2 \mathrm{NH}_{4} \mathrm{OH} \longrightarrow\left(\mathrm{NH}_{4}\right)_{2} \mathrm{CO}_{3}+\mathrm{H}_{2} \mathrm{O}$

3. $\left(\mathrm{NH}_{4}\right)_{2} \mathrm{CO}_{3}+\mathrm{SrCl}_{2} \longrightarrow \mathrm{SrCO}_{3}+2 \mathrm{NH}_{4} \mathrm{Cl}$

4. $2 \mathrm{SrCO}_{3}+5 \mathrm{Mg} \longrightarrow \mathrm{SrC}_{2}+\mathrm{SrO}+5 \mathrm{MgO}$

5. $\mathrm{SrC}_{2}+\mathrm{H}_{2} \mathrm{O} \longrightarrow \mathrm{C}_{2} \mathrm{H}_{2}+\mathrm{SrO}$

6. $3 \mathrm{NaBH}_{4}+4 \mathrm{BF}_{3}\left(\mathrm{C}_{2} \mathrm{H}_{5}\right)_{2} \mathrm{O} \stackrel{\text { Diglyme }}{\longrightarrow}$ $\mathrm{B}_{2} \mathrm{H}_{6}$-activated 7. $3 \mathrm{C}_{2} \mathrm{H}_{2} \underset{\text { silica-alumina }}{\longrightarrow} \mathrm{C}_{6} \mathrm{H}_{6}$

Reactions 1 through 5 were employed by Suess (1954) in the synthesis of $\mathrm{C}_{2}{ }^{14} \mathrm{H}_{2}$ for radiocarbon dating. Reaction 4 is conducted in essentially the manner described by Suess, except for the ratio of $\mathrm{SrCO}_{3}$ to $\mathrm{Mg}$ employed. Strontium carbonate, after heating to $600^{\circ} \mathrm{C}$ to remove traces of ammonia, is reduced to strontium carbide using a mixture of $92 \mathrm{~g}$ of $\mathrm{SrCO}_{3}$ to $83 \mathrm{~g}$ of $\mathrm{Mg}$ powder (40 mesh). The carbon yield for Reactions 4 and 5 combined is now consistent at $95 \%$. Five percent of this $\mathrm{C}_{2} \mathrm{H}_{2}$ is lost, however, to cooled charcoal during the purification of the acetylene.

Reaction 6 is employed in the production of diborane (Brown and Tierney, 1958) for activation of the silica-alumina catalyst. Diborane is routinely produced in a hood-mounted manifold and passed continuously into

* In cooperation with the University of Mississippi and Mississippi Agricultural Experiment Station. 
columns containing the silica-alumina. The present system (McDowell and Ryan, mss., in preparation) is designed to produce about 2 moles of diborane which is sufficient to activate 10 columns of silica-alumina. Each column (ca. $300 \mathrm{~g}$ silica-alumina) will yield about $4.5 \mathrm{~g}$ of $\mathrm{C}_{6}{ }^{14} \mathrm{H}_{6}$ (Reaction 7 ) for counting.

The counting is performed by a Packard "Tri-Carb" liquid-scintillation spectrometer (Model 314AS) equipped with two counting channels and operating at 840 volts with discriminator control settings of 110-500-1000 for $\mathrm{AA}^{\prime}, \mathrm{B}$, and $\mathrm{C}$ discriminators, respectively. The sample chamber is shielded by 4 in. of iron; additional shielding of the preamplifiers, multiplier phototubes, and counting chamber is provided by 2 in. of mercury $(2100 \mathrm{lb})$.

The counting solution consists of benzene $(3.2518 \mathrm{~g})$ synthesized from the sample carbon and the scintillators PPO $(0.5 \%$ by weight $)$ and POPOP $(0.02 \%$ by weight $)$. The counting vial used for most of the measurements in this list is constructed of low-potassium glass cemented to an aluminum base with white epoxy glue. The vial (3.5-cc capacity) was designed to provide a better relationship between the background counting rate and counting efficiency. The background counting rate for this vial is $2.34 \mathrm{cpm}$ at about $50 \%$ counting efficiency. Presently, old samples, sample size permitting, ( $16 \mathrm{~g} \mathrm{C}_{6}{ }^{14} \mathrm{H}_{6}$ ), are counted in a vial having a capacity of $17 \mathrm{cc}$ with a background counting rate of $7.10 \mathrm{cpm}$ at about $52 \%$ efficiency. The counting solution and chamber are cooled to about $8^{\circ} \mathrm{C}$ to reduce thermal noise in the multiplier phototubes.

Quenching checks are made on each sample of benzene using the ratio of counting rates observed in the two channels of the spectrometer.

The contemporary carbon standard, taken as $95 \%$ of the activity of the NBS oxalic-acid standard, is $7.04 \mathrm{cpm} / \mathrm{g}$ carbon. This value is in agreement with values determined for pre-1900 wood corrected to A.D. 1950 (see date list). Data have been calculated on the basis of a $\mathrm{C}^{14}$ half-life of $5570 \mathrm{yr}$ in agreement with the decision of the Fifth Radiocarbon Dating Conference (Godwin, 1962). Errors listed include the standard deviations $(1 \sigma)$ of the counting rates of the contemporary samples, the unknown samples, and the background. Calculated errors less than $100 \mathrm{yr}$ have been increased to that figure as a minimum.

Corrections have not been made for isotopic fractionation in the synthesis of benzene. Previous mass-spectrometric $\mathrm{C}^{13}$ measurements on acetylene samples (Craig, 1953; Suess, 1954) showed a loss of $\mathrm{C}^{14}$ ranging from 1.5 to $3.5 \%$. Since the overall carbon yield in the $\mathrm{C}_{6} \mathrm{H}_{6}$ synthesis ranges from 50 to $60 \%$, fractionation is possible. Repeated analyses of the same sample (see date list) indicate that fractionation is reproducible within the limits of the counting statistics; hence errors resulting from fractionation are minimal.

\section{ACKNOWLEDGMENTS}

We acknowledge the cooperation of the following radiocarbon dating laboratories who supplied interlaboratory check samples: USGS, Yale, Lamont, Shell, University of Michigan, and University of Texas. In addition, we are grateful for the technical assistance offered by Meyer Rubin, USGS, and J. J. 
Stipp, Packard Instrument Company, Inc. We especially appreciate the loan of a print-out recorder and other electronic components by Packard Instrument Company, Inc.

\section{SAMPLE DESCRIPTIONS}

\section{Contemporary carbon series}

\section{CONTEMPORARY SAMPLES}

Quadruplicate syntheses of $\mathrm{C}_{6}{ }^{14} \mathrm{H}_{6}$ were made from 3 different sources of contemporary carbon to determine the reproducibility of the chemical and counting procedures. All values have been corrected to A.D. 1950.

NBS Oxalic Acid $\mathrm{C}^{14}$ standard; $95 \%$ value

$\begin{array}{cr}\text { Sample No. } & c p m / g \text { Carbon } \\ \text { OX-48. } & \mathbf{7 . 1 0} \pm \mathbf{0 . 1 0} \\ \text { OX-72. } & \mathbf{6 . 9 8} \pm \mathbf{0 . 1 0} \\ \text { OX-87. } & \mathbf{6 . 9 9} \pm \mathbf{0 . 1 0} \\ \text { OX-89. } & \mathbf{7 . 0 8} \pm \mathbf{0 . 1 0} \\ \text { Average } & \mathbf{7 . 0 4} \pm \mathbf{0 . 0 5}\end{array}$

Wood from foundation post of Greenwade House, log cabin built in middle 1850's in Brazos River Valley near Whitney, Texas ( $31^{\circ} 54^{\prime} \mathrm{N}$ Lat, $97^{\circ} 23^{\prime} \mathrm{W}$ Long). Coll. 1950 by R. L. Stephenson; subm. by E. B. Jelks, Texas Archeol. Salvage Project, Univ. of Texas, Austin. Comment: sample subm. by J. J. Stipp as an interlaboratory standard. Dated by Univ. of Texas as Tx-43 (Univ. of Texas II).

$\begin{array}{cc}\text { Sample No. } & \text { cpm } / \mathrm{g} \text { Carbon } \\ \text { OX-62. } & \mathbf{6 . 9 3} \pm \mathbf{0 . 1 0} \\ \text { OX-65. } & \mathbf{7 . 0 6} \pm \mathbf{0 . 1 0} \\ \text { OX-67. } & \mathbf{6 . 8 7} \pm \mathbf{0 . 1 0} \\ \text { OX-82. } & \mathbf{6 . 9 0} \pm \mathbf{0 . 1 0} \\ \text { Average } & \mathbf{6 . 9 4} \pm \mathbf{0 . 0 5}\end{array}$

Wood, Quercus borealis, from a tree cut in 1964 in Holly Springs Natl. Forest, Holly Springs, Mississippi (34 $27^{\prime} \mathrm{N}$ Lat, $89^{\circ} 23^{\prime}$ W Long). Tree showed 107 growth rings. Coll. 1964 and subm. by T. L. Price, U. S. Forest Service and L. L. McDowell, USDA, Oxford, Mississippi.

$\begin{array}{ccc}\text { Sample No. } & \text { Tree Rings } & \text { cpm } / \mathrm{g} \text { Carbon } \\ \text { OX-78. } & \mathbf{1 8 5 7 - 1 8 6 7} & \mathbf{6 . 8 9} \pm \mathbf{0 . 1 0} \\ \text { OX-84. } & 1857-1867 & \mathbf{6 . 8 9} \pm \mathbf{0 . 1 0} \\ \text { OX-69. } & 1877-1882 & \mathbf{6 . 9 5} \pm \mathbf{0 . 1 0} \\ \text { OX-80. } & 1877-1882 & 6.89 \pm \mathbf{0 . 1 0} \\ \text { Average } & & 6.90 \pm \mathbf{0 . 0 5}\end{array}$


General Comment: mean values for wood from the Greenwade House, Texas, and from the Quercus borealis, Mississippi are $93.9 \pm 0.8 \%$ and $93.4 \pm$ $0.8 \%$, respectively, of the NBS oxalic-acid standard.

\section{INTERLABORATORY CHECK SAMPLES}

\section{OX-1. White Pine Copper Mine, Michigan \\ $10,420 \pm 220$ \\ $\mathbf{8 4 7 0}$ в.c.}

Spruce $\log$ from till exposed inside of kettle, White Pine Copper Mine, $\mathbf{N}$ dam of S Tailings Pond, $500 \mathrm{ft} \mathrm{E}$ of former bed of Caribou Creek, near center NE $1 / 4$ NE $1 / 4$, Sec. 2, T 50 N, R 42 W $\left(46^{\circ} 45^{\prime} \mathrm{N}\right.$ Lat, $89^{\circ} 34^{\prime}$ W Long $)$, Ontonagon County, Michigan. Coll. 1960 and subm. by F. J. Brandtner. Comment (L.L.M.) : interlab. check, dated by USGS as W-964, 10,230 \pm 280 (USGS VII).

\section{OX-2. Brønlund Fjord, Greenland}

$5050 \pm 130$ 3100 в.с.

Driftwood from alt $35 \mathrm{ft}$ on surface of marine terrace, $2 \mathrm{mi}$ NE of Kap Harold Moltke (82 $10^{\prime} \mathrm{N}$ Lat, $29^{\circ} 50^{\prime} \mathrm{W}$ Long), E end of Brønlund Fjord, N Greenland. Terrace is formed of silt with thin veneer of stones. Coll. 1957, 1960 and subm. by W. E. Davies. Comment (L.L.M.) ; interlab. check, dated by USGS as W-1073, $4970 \pm 260$ (USGS VII).

\section{OX-3. Promontory Point, Utah}

$20,400 \pm 420$

\section{8,450 в.C.}

Wood from large gravel pit on $\mathrm{S}$ tip of Promontory Point $\left(41^{\circ} 14^{\prime} \mathrm{N}\right.$ Lat, $112^{\circ} 29^{\prime} \mathrm{W}$ Long), Boxelder County, Utah, W of Ogden. Tremendous exposures were made in the sediments of Lake Bonneville in order to obtain material for this new embankment of the Southern Pacific R.R. across Great Salt Lake. Three gravel pits were created at near-Provo levels. Samples were collected from above the middle-elevation spit, but stratigraphy was so disturbed by the pit operation that the relation of the bog deposits, from which the wood came, to the spit is questionable. Wood is from bog deposits $600 \mathrm{ft} \mathrm{S}$ of W-875 and at ca. $4775 \mathrm{ft}$ alt. Coll. 1959 by J. R. Rubin and M. Rubin. Comment (L.L.M.) : interlab. check, dated by USGS as W-876, 20,600 \pm 500 (USGS V).

\section{OX-4. Mesters Vig, Greenland}

Driftwood from NE slope, cut bank at $\mathrm{N}$ tip of second delta section $\mathrm{NW}$ of Tunnelelv, at Hesteskoen, alt 19 to $20 \pm 1 \mathrm{~m}$. Coll. 1960 and subm. by A. L. Washburn, Yale Univ. Comment (L.L.M.) : interlab. check, dated by Yale as Y-879, $7460 \pm 130$ (Yale VII).

\section{OX-43. Mesters Vig, Greenland}

$$
\pm 120
$$

Driftwood from NE slope, inner edge of emerged strandline on delta at Noret outlet of Tunnelelv, at Korsbjerg, alt $3 \pm 0.5 \mathrm{~m}$. Coll. 1960 and subm. by A. L. Washburn. Comment (L.L.M.) : interlab. check, dated by Yale as Y-702, $735 \pm 110($ Yale VII). 


\section{OX-55. Oxford, Mississippi}

Wood from excavation made on Highway 6 Bypass during construction of a box bridge on Burney Branch, NE 1/4. SE 1/4 Sec. 28, T 8 S, R 3 W (34 ${ }^{\circ}$ $22^{\prime} \mathrm{N}$ Lat, $89^{\circ} 31^{\prime} \mathrm{W}$ Long). From log imbedded in silt loam soil (ca. $2 \%$ organic matter) $10 \mathrm{ft}$ below surface of creek and $18 \mathrm{ft}$ below floodplain. The silt-loam soil is covered by $8 \mathrm{ft}$ of recent alluvium (principally sand and silt low in organic matter) probably deposited since 1835 when area was first opened to settlement (Happ et al., 1940, p. 4; Hilgard, 1860, p. 293). Coll. and subm. in 1964 by Russell Woodburn, Univ. of Mississippi. Comment: date may represent age of old pond or creek deposit. Age is the average of two determinations:

$$
\begin{array}{ll}
\text { OX-55 } & 4980 \pm 100 \\
\text { OX-77 } & 5040 \pm 100
\end{array}
$$

Date lists:

\section{ReFERENCES}

USGS V Rubin and Alexander, 1960

USGS VII Ives, Levin, Robinson, and Rubin, 1964

University of Texas Tamers, Pearson, and Davis, 1964

Yale VII Stuiver and Deevey, 1962

Brown, H. C., and Tierney, P. A., 1958, Reactions of Lewis acids of boron with sodium hydride and borohydride: Jour. Am. Chem. Soc., v. 80, p. 1552-1558.

Craig, Harmon, 1953, The geochemistry of the stable carbon isotopes: Geochim. et Cosmochim. Acta, v. 3, p. 53-92.

Godwin, H., 1962, Half-life of radiocarbon: Nature, v. 195, p. 984.

Happ, S. C., Rittenhouse, Gordon, and Dobson, G. C., 1940, Some principles of accelerated stream and valley sedimentation: U. S. Dept. of Agriculture, Tech. Bull. no. 695, p. 133.

Hilgard, E. W., 1860, Report on the geology and agriculture of the State of Mississippi: Jackson, Mississippi, p. 391.

Ives, P. C., Levin, Betsy, Robinson, R. D., and Rubin, Meyer, 1964, U. S. Geological Survey radiocarbon dates VII: Radiocarbon, v. 6, p. 37-76.

McDowell, L. L., and Ryan, M. E., 1964, Radiocarbon dating by liquid scintillation spectrometry: the synthesis of benzene $\left(\mathrm{C}_{8}{ }^{14} \mathrm{H}_{6}\right)$ : U. S. Dept. of Agriculture, ARS-4l-88.

Noakes, J. E., Isbell, A. F., Stipp, J. J., and Hood, D. W., 1963, Benzene synthesis by low temperature catalysis for radiocarbon dating: Geochim. et Cosmochim. Acta, v. 27, p. $797-804$.

Olson, E. A., and Broecker, W. S., 1958, Sample contamination and reliability of radiocarbon dates: New York Acad. Sci. Trans., v. 20, p. 593-604.

Rubin, Meyer, and Alexander, Corrinne, 1960, U. S. Geological Survey radiocarbon dates V: Am. Jour. Sci. Radioc. Supp., v. 2, p. 129-185.

Suess, H. E., 1954, Natural radiocarbon measurements by acetylene counting: Science, v. 120 , p. $5-7$.

Stuiver, Minze, and Deevey, E. S., 1962, Yale natural radiocarbon measurements VII: Radiocarbon, v. 4, p. $250-262$

Tamers, M. A., Stipp, J. J., and Collier, J., 1961, High sensitivity detection of naturally occurring radiocarbon: chemistry of the counting sample: Geochim. et Cosmochim. Acta, v. 24 , p. $266-276$.

Tamers, M. A., Pearson, F. J., Jr., and Davis, Mott, 1964, University of Texas radiocarbon dates II: Radiocarbon, v. 6 , p. 138-159. 